\title{
Final Height in Short Children Born Small for Gestational Age Treated with Growth Hormone
}

\author{
JOVANNA DAHLGREN AND KERSTIN ALBERTSSON WIKLAND; ON BEHALF OF THE \\ SWEDISH STUDY GROUP FOR GROWTH HORMONE TREATMENT \\ Göteborg Pediatric Growth Research Center, Institute for the Health of Women and Children, The \\ Sahlgrenska Academy at Göteborg University, 41685 Göteborg, Sweden
}

\begin{abstract}
ABST
The aim of this observational study was to assess the long-
term growth responses to $\mathrm{GH}$ treatment of children born small
for gestational age (SGA). GH treatment was begun before
puberty and continued to final height $(\mathrm{FH})$. Seventy-seven short
(height $\mathrm{SD}$ score below -2$)$ prepubertal children born SGA
(below $-2 \mathrm{SD}$ for birth weight and/or birth length), with a broad
range of GH secretory capacity, were treated with GH in a daily
dose of $33 \mu \mathrm{g} / \mathrm{kg}(0.1 \mathrm{U} / \mathrm{kg})$, beginning before the onset of
puberty. We observed a difference between adult and pretreat-
ment projected height of $1.3 \mathrm{SD}(9 \mathrm{~cm})$ for the entire group.
Among the children treated for $>2 \mathrm{y}$ before puberty, this mean
gain $(i . e$. difference) in final height was $1.7 \mathrm{SD}$, whereas the
mean gain was $0.9 \mathrm{SD}$ among those in whom treatment was
begun $<2 \mathrm{y}$ before puberty. Better catch-up growth was observed
in the younger $(r=-0.56, p<0.0001)$, shorter $(r=-0.49$,
$p<0.0001)$, and lighter $(r=-0.46, p<0.0001)$ subjects. We
conclude that GH treatment improves the final height of short
\end{abstract}
There is a 5- to 7-fold higher risk of short stature among adults who were born SGA, compared with those born AGA $(1,2)$. Children born SGA comprise one-third of children who are short during childhood (1). As short stature is present in $10-15 \%$ of children born SGA (1-3), efforts have been made to understand the etiology of their growth restriction and to increase their FH.

Birth length has been shown in population-based studies to be the single most important predictor of adult height $(1,2)$. Short children born SGA keep their prepubertal height SDS to $\mathrm{FH}$, whereas short children born AGA gain further 0.6-0.7 SDS in height during puberty (4). French data show that adult

Received August 22, 2003; accepted July 12, 2004

Correspondence: Jovanna Dahlgren, Ph.D., The Sahlgrenska Academy at Göteborg University, Institute for the Health of Women and Children, Department of Pediatrics/ GP-GRC, The Queen Silvia Children's Hospital, SE-416 85 Göteborg, Sweden; e-mail: Jovanna.Dahlgren@vgregion.se

Supported by grants from the Swedish Medical Research Council (no. 7509), the Tore Nilsson Foundation, the Magnus Bergwall Foundation, the University of Göteborg, and an unrestricted grant from Pharmacia/Pfizer.

Participants in the Swedish Study Group for GH treatment: Kerstin Albertsson Wikland, Stefan Aronsson, Jan Gustafsson, Lars Hagenäs, Anders Häger, Sten Ivarsson, Berit Kriström, Karl-Olof Nilsson, Martin Ritzén, Torsten Tuvemo, Ulf Westgren, and Otto Westphal.

DOI: 10.1203/01.PDR.0000148716.71231.81 children born SGA. The height gain attained before the onset of puberty is maintained to final height. The younger, shorter, and lighter the child at the start of GH treatment, the better the response. Moreover, most of these SGA individuals treated with GH reach their target height. (Pediatr Res 57: 216-222, 2005)
Abbreviations
AGA, appropriate for gestational age
AITT, arginine-insulin tolerance test
Diff SDS, the intrafamily difference in SDS (i.e. the difference
in height SDS of the child compared with his/her MPH SDS)
FH, final height
GHD, GH deficient
MPH, mid-parental height SDS
SDS, SD score
SGA, small for gestational age

men who were born SGA are, on average $7.5 \mathrm{~cm}$, and women are $9.6 \mathrm{~cm}$ below their mid-parent target height (5). This is at the lower end of the range compared with other studies $(1,6,7)$, which find a growth deficit of 0.7-0.9 SDS below the MPH.

Either low GH secretion or reduced sensitivity to GH may account for some of the growth retardation of children born SGA (8-10). Boguszewski et al. $(11,12)$ reported that short children born SGA have both lower mean GH secretion rates and lower serum IGF-I (IGF-I) values than children born AGA. In children born SGA, there is a correlation between the $\mathrm{GH}$ dose and the growth response, mainly during prepubertal years (13-16). The majority of short children born SGA show improvement in growth rate during $\mathrm{GH}$ treatment, particularly if treatment is begun early $(14,16)$. With the exception of one large study (17), however, no information is available on the FH achieved by short children born SGA and treated with GH from a young age to FH. We report here the observational data on the effect of GH therapy on final height of children born SGA.

\section{METHODS}

Study subjects. A total of 77 prepubertal, short children (63 boys and 14 girls) born SGA between 1973 and 1984 participated in this observational 
study. The children were followed either in the National Registry of GH treatment $(n=41)$ or in GH treatment trials $(n=36)$ that were conducted in non-GHD short children. They were treated with GH, $33 \mu \mathrm{g} / \mathrm{kg}(0.1 \mathrm{U} / \mathrm{kg})$ daily. At the start of puberty, 28 children in trials of GH treatment in GHD and/or short children (TR 88-177 and TR 288-080) were randomized within each trial to a daily GH dose of $33 \mu \mathrm{g} / \mathrm{kg}(0.1 \mathrm{U} / \mathrm{kg})$ or $66 \mu \mathrm{g} / \mathrm{kg}(0.2 \mathrm{U} / \mathrm{kg})$. Half of the children in the study were followed at Queen Silvia Children's Hospital, Göteborg, and the other half in other university hospitals in Sweden. For some analyses, the children were divided into groups according to the duration of treatment before puberty: group $1(n=36)$ children were treated for $>2 \mathrm{y}$ before puberty (mean, $4.2 \mathrm{y}$; range, 2.1 to 10.0$)$, and group $2(n=41)$ were treated for $<2$ y before puberty (mean, $1.0 \mathrm{y}$; range, 0.2 to 2.0 ). This division is in line with the goal to treat with $\mathrm{GH}$ for at least $2 \mathrm{y}$ before puberty, to obtain a full catch-up growth before start of puberty (18).

All children were born either light $\left(\mathrm{SGA}_{\mathrm{W}}, n=10\right)$, short $\left(\mathrm{SGA}_{\mathrm{L}}, n=10\right)$, or both short and light $\left(\mathrm{SGA}_{\mathrm{wL}}, n=57\right)$, i.e. below $-2 \mathrm{SD}$ in birth weight or birth length, according to the Swedish reference for newborns (19). Twelve percent $(n=8)$ were born before $37 \mathrm{wk}$ of gestation (range, 30-36 wk). None had evidence of serious complications in the neonatal period, i.e. signs of severe asphyxia (defined as an Apgar score $<3$ after 5 min) or of sepsis. Their growth had been monitored from birth at neonatal and child healthcare units. None showed complete postnatal catch-up growth, and all were still short (below -2 SD) at the start of GH therapy. They were well nourished and showed no clinical evidence of psychosocial disorders.

Children were excluded from the study if they had chromosomal disorders, serious malformations, chondrodysplasia, or maternal history of alcohol or drug addiction, or a condition requiring chronic medical treatment in the child. Thyroid, kidney, and liver function tests were normal. One boy with SilverRussell syndrome was included and followed to FH. No child was allowed to enter if puberty began before the start of GH treatment ( 25 children excluded). The start of the puberty was defined as breast stage 2 for girls (20) and testicular volume $>4 \mathrm{~mL}$ for boys (21). Treatment with gonadotropin releasing hormone $(\mathrm{GnRH})$-analogs because of early puberty was also a criterion for exclusion (14 children excluded). These children treated with GnRH-analogs did reach a FH (SDS) in the same range as those without early puberty (data not shown). After the above exclusions, the group of children born SGA who started GH treatment during the given period consisted of 88 prepubertal children. However, 11 children were excluded as they either were not motivated to inject GH daily after $0.8-4.5 \mathrm{y}$ of treatment despite ongoing catch-up growth (5 children) or had signs of GH insensitivity ( 6 children). The final height of 10/11 is known and the mean was -2.5 SDS (mean target height, -0.9 SDS). (See Table 2 for clinical characteristics.) The total flow of patients is presented in Figure 1.

Age at start of GH treatment ranged from 2.5 to $15.1 \mathrm{y}$. Thus, height SDS for prepubertal children had to be obtained from the childhood part in the Swedish reference. The childhood reference gives an accurate estimate of height, as it does not underestimate height if puberty is delayed (22). Achieved FH was defined as the time point $1 \mathrm{y}$ after height velocity $<1 \mathrm{~cm} / \mathrm{y}$. The
GH treated short prepubertal children born SGA 1973-84

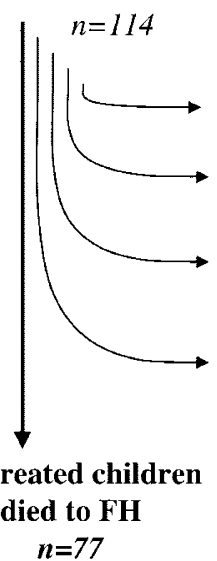

Non-GH treated short prepubertal children born SGA 1972-82

GnRH-analog
:
Non GH-treated children
studied to FH
$n=34$

Figure 1. Flow chart of short prepubertal children born SGA. Out of 114 short GH-treated children born SGA, 77 were prepubertal at GH start and without concomitant disease. These 77 children were included in this study. Growth of another 34 short prepubertal children born SGA was recorded in the comparison group. projected FH was calculated compared with the height of the reference population (23) and the gain in FH defined as the projected adult height in SDS minus the achieved adult height in SDS.

Maternal and paternal heights SDS were compared with the Swedish reference values (23), and the MPH in SDS was obtained, with the formula maternal height in SDS plus paternal height in SDS divided by two. The difference in height SDS of the child compared with his/her MPH SDS is expressed as intrafamily difference in SDS (Diff SDS). Birth data, MPH and clinical characteristics at start of GH treatment are shown in Table 1.

Comparison group. Thirty-four untreated short prepubertal SGA children (17 girls and 17 boys) served as a comparison group (no randomized control group). They were born in Göteborg between 1972 and 1982 after uncomplicated pregnancies, and had their growth monitored from birth to FH. All children had a height below -2 SD at 2 y of age and below -1.6 SD during prepubertal years (mean, $-2.2 \mathrm{SD}$; range, -3.5 to $-1.6 \mathrm{SD}$ ). MPH SDS for the group was $-1.1 \pm 0.7$ (mean $\pm \mathrm{SD}$ ). See Table 2 for more data.

Hormonal tests. A standard AITT was performed in all but two children (24). In these two, the spontaneous $24-\mathrm{h} \mathrm{GH}$ secretion profile was performed (25). In 21 of the 77 children (37\%), the maximal serum GH (GH max) response was below $5.3 \mu \mathrm{g} / \mathrm{L}(16 \mathrm{mU} / \mathrm{L})$, the cut-off criteria used for severe GH deficiency at the time of diagnosis. Age at start of GH treatment did not differ between GHD and non-GHD children (data not shown).

GH concentrations were measured using a polyclonal antibody-based immunoradiometric assay (Pharmacia Diagnostics, Uppsala, Sweden), using the World Health Organization (WHO) First International Reference Preparation (IRP) 66/217 as the standard. For samples from 11 children, however, the IRP $80 / 505$ was used as the standard, and the values obtained were transformed to the WHO IRP 66/217 standard (26).

IGF-I was measured with an IGFBP-blocked RIA without extraction and in the presence of an approximately 250 -fold excess of IGF-II (27). Independent of sex, age, and pubertal development, all values were converted into SD scores using a mathematical formula, based on reference values from healthy prepubertal and pubertal children (28).

Study protocol. Recombinant human GH was administered subcutaneously in a daily dose of $33 \mu \mathrm{g} / \mathrm{kg}$ body weight. During puberty, 24 children (17 males $/ 7$ females) were randomized to a dose of $66 \mu \mathrm{g} / \mathrm{kg} / \mathrm{d}$ (within two clinical trails: TR 88-177 and TR 288-080). GH treatment was stopped when growth velocity was $<1 \mathrm{~cm} / \mathrm{yr}$, and height was monitored for at least two more years.

The GH treatment was approved by the ethical committee of the Medical Faculties of the Universities of Göteborg, Lund, Linköping, Uppsala, and Umeå, and of the Karolinska Institute. Informed consent was obtained from all children (if old enough) and their parents. Parts of the results have been reported previously (4).

Statistical methods. Data are presented as means $\pm \mathrm{SD}$, unless otherwise stated. All correlation analyses were made with Spearman nonparametric rank correlation. The Mann-Whitney $U$ test was used for comparison of longitudinal data between two groups. Multiple stepwise regression analysis was performed, after transforming the dependent variable to normal distribution by calculating normal score using Blom's method (29), to find multivariate variables explaining height gain. Variables entered into the regression analysis were those with a $p$ value $<0.1$ with univariate analysis. Duration of GH treatment was not included in the analysis, as it is a variable dependent on age at start of treatment and age at start of pubertal growth spurt. All tests were two tailed and conducted at a 5\% level of significance.

\section{RESULTS}

Normalizing final height. The mean final height of the group was $-1.2 \mathrm{SDS}$ (corresponding to $172 \mathrm{~cm}$ in males and $159 \mathrm{~cm}$ in females) (Fig. 2), entirely reaching the mean MPH of -1.2 SDS. Figure 3 shows the Diff SDS at start versus the Diff SDS at FH for both treated and untreated children. The final height of $86 \%$ of the GH-treated children was within their target height (i.e. their FH was within 1 SDS from their MPH), whereas the final height of only $52 \%$ of those in the untreated comparison group was within their target height $(p<0.001)$.

Total growth response. For the entire group, we observed a mean gain in height $\mathrm{SD}$ of $1.3 \mathrm{SD} \pm 0.8(9 \mathrm{~cm})$ from the start 
Table 1. Clinical characteristics

\begin{tabular}{|c|c|c|c|c|c|c|c|c|}
\hline \multirow[b]{2}{*}{ Variables } & \multirow{2}{*}{$\begin{array}{c}\text { At birth } \\
\text { Total } \\
(n=77)\end{array}$} & \multicolumn{3}{|c|}{ At start of GH } & \multicolumn{2}{|c|}{ At onset of puberty } & \multicolumn{2}{|c|}{ At final height } \\
\hline & & $\begin{array}{c}\text { Total } \\
(n=77)\end{array}$ & $\begin{array}{c}\mathrm{GH}>2 \mathrm{y} \\
\text { prepub } \\
(n=36)\end{array}$ & $\begin{array}{c}\mathrm{GH}<2 \mathrm{y} \\
\text { prepub } \\
(n=41)\end{array}$ & $\begin{array}{c}\mathrm{GH}>2 \mathrm{y} \\
\text { prepub } \\
(n=36)\end{array}$ & $\begin{array}{c}\mathrm{GH}<2 \mathrm{y} \\
\text { prepub } \\
(n=41)\end{array}$ & $\begin{array}{c}\mathrm{GH}>2 \mathrm{y} \\
\text { prepub } \\
(n=36)\end{array}$ & $\begin{array}{c}\mathrm{GH}<2 \mathrm{y} \\
\text { prepub } \\
(n=41)\end{array}$ \\
\hline Age (wk/y) & $39.3 \pm 2.8$ & $10.7 \pm 2.5$ & $8.9 \pm 2.1$ & $12.3 \pm 1.6^{\ddagger}$ & $12.7 \pm 1.3$ & $13.4 \pm 1.7^{*}$ & $17.4 \pm 1.2$ & $17.8 \pm 1.6$ \\
\hline Height SDS & $-2.7 \pm 0.8$ & $-2.8 \pm 0.7$ & $-3.1 \pm 0.8$ & $-2.5 \pm 0.6^{\dagger}$ & $-1.1 \pm 0.8$ & $-1.6 \pm 0.7 *$ & $-1.2 \pm 0.7$ & $-1.6 \pm 0.8$ \\
\hline Weight SDS & $-4.1 \pm 1.7$ & $-2.0 \pm 1.0$ & $-2.2 \pm 1.0$ & $-1.8 \pm 1.0^{*}$ & $-0.9 \pm 1.0$ & $-1.4 \pm 0.9 *$ & $-0.6 \pm 1.0$ & $-0.6 \pm 1.2$ \\
\hline
\end{tabular}

Clinical characteristics at birth, at start of GH treatment, at onset of puberty, and at final height in children born SGA, expressed as mean \pm SD. The children are subdivided in two groups according $<2$ prepubertal years or $>2$ prepubertal years with GH treatment.

$* p<0.05,{ }^{\dagger} p<0.01,{ }^{\ddagger} p<0.001$ with Mann-Whitney $U$ test.

Table 2. Clinical characteristics of the children in the comparison group and GH-treated children either with bad compliance or poor responders

\begin{tabular}{lrrrrrrr}
\hline & \multicolumn{3}{c}{ At start of study } & & \multicolumn{3}{c}{ At final height } \\
\cline { 2 - 4 } \cline { 5 - 6 } & Age $(\mathrm{y})$ & Height SDS & Diff SDS & & Age $(\mathrm{y})$ & Height SDS & Diff SDS \\
\hline Comparison group $(n=34)$ & $8.3 \pm 0.6$ & $-2.2 \pm 0.5$ & $-1.2 \pm 0.7$ & & $17.3 \pm 1.7$ & $-2.0 \pm 0.8$ & $-0.9 \pm 0.9$ \\
$\begin{array}{l}\text { Bad compliance and poor } \\
\quad \text { responders }(n=11)\end{array}$ & $10.2 \pm 2.5$ & $-3.3 \pm 0.7$ & $-2.3 \pm 1.0$ & & $17.6 \pm 1.2$ & $-2.7 \pm 0.8$ & $-1.7 \pm 1.0$ \\
\hline
\end{tabular}

Results are expressed as mean \pm SD.

of $\mathrm{GH}$ treatment to $\mathrm{FH}$. Among those treated for $>2$ prepubertal years, the gain was $1.7 \mathrm{SDS} \pm 0.7(12 \mathrm{~cm})$, and for those treated $<2$ prepubertal years the gain was $0.9 \mathrm{SDS} \pm 0.7(6$ cm) $(p<0.001)$.

Figure 4 shows the mean height attained from start of treatment to start of puberty and to $\mathrm{FH}$ in the two treated groups and the untreated children. As a mean, the untreated children maintained their height SDS throughout puberty to $\mathrm{FH}$.

No significant difference in height gain was observed when subjects were divided by gender (data not shown) or by GH secretory status (Table 3 ).

Prepubertal growth. The growth response to GH treatment during the prepubertal years was most pronounced among the children treated for the longest duration. Those treated for $>2$ prepubertal years had a prepubertal mean gain in height of 1.8 SDS \pm 0.6 , whereas those treated for $<2$ prepubertal years had a prepubertal mean gain of $0.8 \mathrm{SDS} \pm 0.5(p<0.001$; see Table 3 for more details).

Pubertal growth. There was a significant different gain in height during pubertal period in non-GHD children. If treated $>2$ prepubertal years, there was a slight loss in height SDS compared with those treated $<2$ prepubertal years $(p<0.05)$.

The children who received the higher GH dose $(66 \mu \mathrm{g} / \mathrm{kg} / \mathrm{d})$ during puberty did not exhibit a greater height SDS (Table 4).

Descriptive regression model for $\mathbf{F H}$. Both prepubertal and overall height gain correlated negatively at the start of treatment with age, Diff SDS, height SDS, and weight SDS, but positively with prepubertal years on GH treatment (Table 5). The magnitude of the pubertal growth, correlated with $\mathrm{GH}_{\max }$ during the AITT and with intrafamily Diff SDS at the start of treatment.

Multiple stepwise regression analysis of growth response. Multiple stepwise regression analysis was performed to find multivariate variables explaining the variance in $\mathrm{FH}$ as well as the variance in Diff SDS at FH.

Known variables at start of GH treatment. Paternal height, a subject's height, weight, and age at start of GH treatment, and $\mathrm{GH}_{\max }$ accounted for $51 \%$ of the variance in FH. Sixty percent of the variance in Diff SDS at FH could be explained by the Diff SDS, age, weight and $\mathrm{GH}_{\max }$ at start. See Table 6.

Known variables at onset of puberty. Fifty-six percent of the variance in FH could be explained by the height at onset of puberty, paternal height, $\mathrm{GH}_{\max }$, weight at start, and prepubertal years treated with GH. As much as $66 \%$ of the variance in Diff SDS at FH could be explained by Diff SDS and weight at onset of puberty, as well as the $\mathrm{GH}_{\max }$ at start.

Safety. GH treatment was well tolerated and no adverse events considered to be drug-related were observed.

\section{DISCUSSION}

We have observed that long-term GH treatment in short children who were born SGA results in an FH corresponding to the height of their parents, i.e. a mean FH of $-1.2 \mathrm{SD}$ after a gain of $1.3 \mathrm{SD}(9 \mathrm{~cm})$. The benefit of GH treatment on FH is greatest among the children who are younger, shorter, and lighter at the start of treatment. Treatment has the most benefit when it is started before the pubertal growth spurt begins. This prepubertal gain is maintained through puberty to FH. Among our subjects in whom GH treatment was begun $>2$ y before puberty, the mean gain in FH was $1.7 \mathrm{SD}(12 \mathrm{~cm})$ but only 0.9 SD $(6 \mathrm{~cm})$ if begun $<2$ y before puberty.

The target height range of $-1.2 \mathrm{SD}$ of the parents of our subjects is similar to that reported from other studies of children born SGA $(12-14,16)$. The children treated for $>2$ y before puberty reached a mean $\mathrm{FH}$ of $-1.2 \mathrm{SD}$, equal to the mean target height, whereas those treated for $<2$ y before 

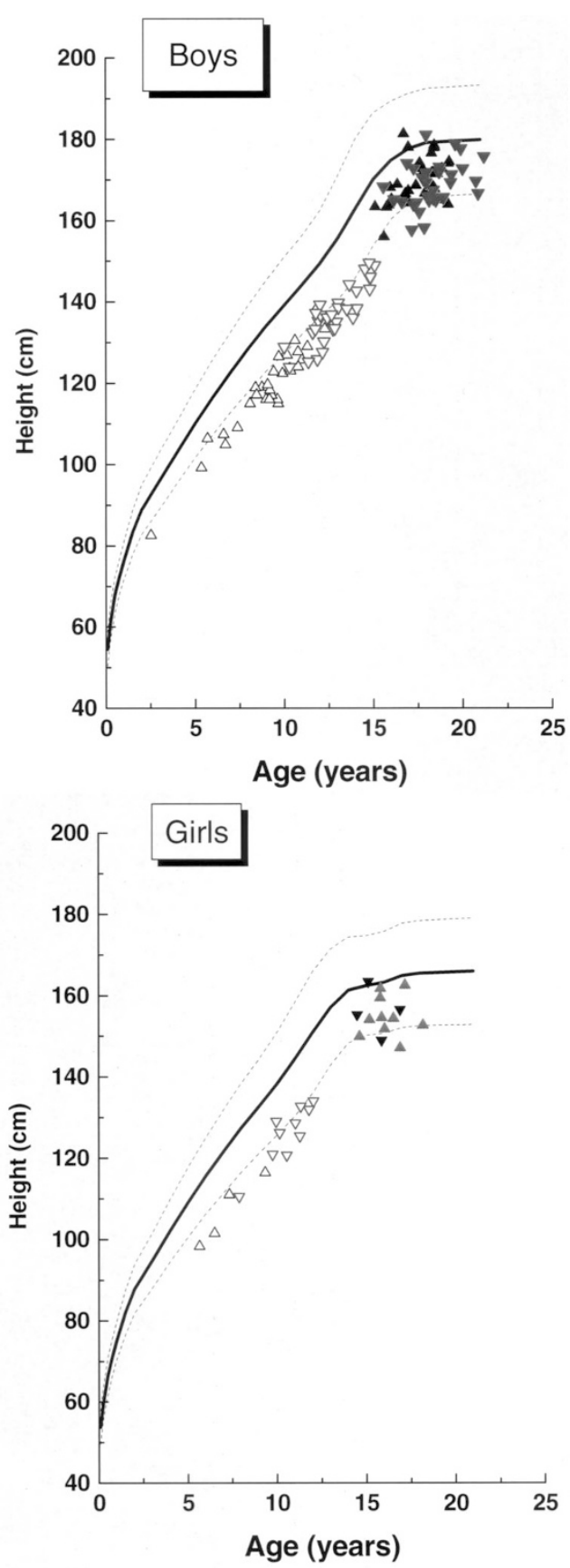

Figure 2. Height SDS at start and FH. Height SDS in boys (left) and girls (right) at the start of $\mathrm{GH}$ treatment (open triangles) and at final height (filled triangles). The regular triangles denote the patients treated $>2 \mathrm{yr}$ before puberty, and inverted triangles are those treated $<2 \mathrm{yr}$ before puberty. The growth curves are from the reference population (23).

puberty had a mean FH of $-1.6 \mathrm{SD}$. Nevertheless, nearly $90 \%$ of the GH-treated children achieved an FH within $1 \mathrm{SD}$ of the target height, whereas only $50 \%$ of the untreated children achieved this-a finding in agreement with our populationbased study of untreated short children born SGA (1).

Most of the reports on results of GH treatment on FH of short children born SGA are nonrandomized studies composed of small numbers of participants $(30,31)$, or include only GHD children (17), many of whom entered puberty during the first year of treatment $(17,30,31)$. Among children treated at a later

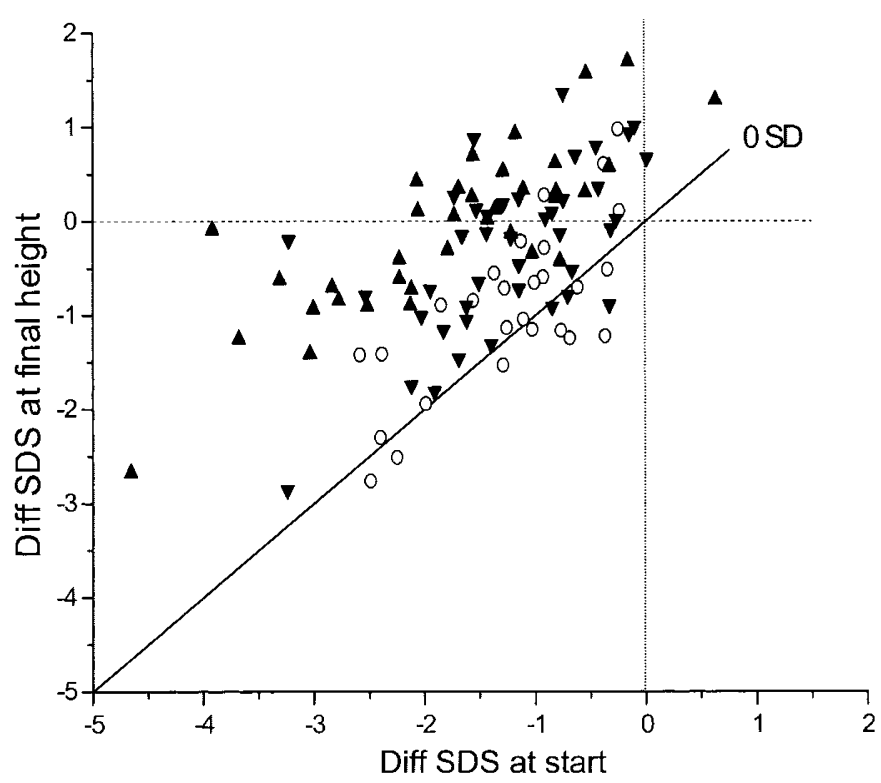

Figure 3. The change in Diff SDS. The parent-adjusted height (Diff SDS) at start $v s$ the Diff SDS at FH for each child is shown. Untreated children are shown as circles, children treated for $<2$ prepubertal years as inverted triangles and for $>2$ prepubertal years as regular triangles. The diagonal solid line depicts no change in Diff SDS. Individuals at or below this line have not obtained any gain in Diff SDS.

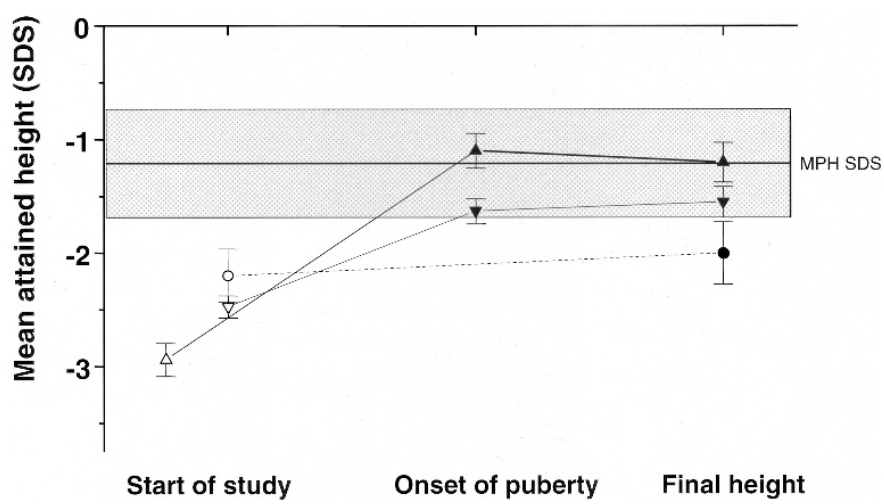

Figure 4. The mean attained height. The prepubertal and pubertal height gain (SDS) in the two GH-treated groups, expressed as mean and SE: regular triangles $=$ treated $>2$ y before puberty, and inverted triangles $=$ treated $<2$ $\mathrm{y}$ before puberty. Attained height in the untreated group is shown as circles and broken line, expressed as mean and SE. Mean MPH $\pm 0.5 \mathrm{SD}$, is shown as shadowed area.

age, a gain at near FH of $1 \mathrm{SD}$ has been observed (30), a value comparable to the $0.9 \mathrm{SD}$ for our subgroup of children treated for $<2$ y before puberty. However, data on the $\mathrm{FH}$ achieved in children born SGA if treated from a younger age to $\mathrm{FH}$ is lacking. Zucchini et al. (31) studied GH treatment to FH among short children born light $\left(\mathrm{SGA}_{\mathrm{W}}\right)$. He found that less than one-third had an FH within the target height range. The difference between this outcome and our finding that $90 \%$ of GH treated subjects reach their target might be related to the longer duration of GH treatment of our patients before puberty. Coutant et al. (17) also reported that GH treatment had a limited effect on the FH (mean gain of 0.6 SDS) of short children born SGA, and having the diagnosis of GHD. However, a low dose of $\mathrm{GH}(13.3 \mu \mathrm{g} / \mathrm{kg} / \mathrm{wk}, 0.4 \mathrm{U} / \mathrm{kg} / \mathrm{wk})$ was 
Table 3. Longitudinal change in height

\begin{tabular}{|c|c|c|c|c|}
\hline & \multicolumn{4}{|c|}{ Delta height SDS } \\
\hline & Birth-GH start & GH start-pub start & Pub start-FH & GH start-FH \\
\hline Total $(n=77)$ & $-0.1 \pm 0.9$ & $1.3 \pm 0.7$ & $0.0 \pm 0.6$ & $1.3 \pm 0.8$ \\
\hline$>2 \mathrm{y}(n=9)$ & $-0.4 \pm 0.6$ & $1.6 \pm 0.4$ & $0.2 \pm 0.5$ & $1.9 \pm 0.5$ \\
\hline$<2$ y $(n=11)$ & $0.3 \pm 0.9$ & $1.0 \pm 0.4^{\dagger}$ & $0.2 \pm 0.6$ & $1.2 \pm 0.7^{*}$ \\
\hline \multicolumn{5}{|l|}{ Non-GHD } \\
\hline
\end{tabular}

Longitudinal change in height expressed in delta height SDS, in GH-treated children either with GHD or non-GHD, expressed as means \pm SD. No significant difference was found between GHD and non-GHD. However, there was a significant difference when groups were further subdivided and instead compared according duration of prepubertal treatment [more than 2 pubertal years $(>2 \mathrm{y})$ or less than 2 prepubertal years $(<2 \mathrm{y})$ ].

$* p<0.05,{ }^{\dagger} p<0.01,{ }^{\ddagger} p<0.001$ with Mann-Whitney $U$ test.

Table 4. Attained height with different GH doses during puberty

\begin{tabular}{|c|c|c|c|c|c|c|}
\hline & \multicolumn{3}{|c|}{ At start of puberty } & \multicolumn{3}{|c|}{ At final height } \\
\hline & Age (y) & Height SDS & Diff SDS & Age (y) & Height SDS & Diff SDS \\
\hline Total $(n=77)$ & $13.0 \pm 1.5$ & $-1.4 \pm 0.8$ & $-0.2 \pm 1.0$ & $17.6 \pm 1.4$ & $-1.4 \pm 0.8$ & $-0.2 \pm 0.9$ \\
\hline Male $(n=46)$ & $13.5 \pm 1.2$ & $-1.2 \pm 0.8$ & $-0.1 \pm 1.0$ & $17.8 \pm 1.3$ & $-1.3 \pm 0.8$ & $-0.2 \pm 0.9$ \\
\hline Female $(n=7)$ & $11.1 \pm 1.6$ & $-1.8 \pm 0.5$ & $-0.5 \pm 0.6$ & $15.9 \pm 1.0$ & $-1.9 \pm 0.6$ & $-0.5 \pm 0.7$ \\
\hline Double $(n=24)$ & $12.8 \pm 1.7$ & $-1.6 \pm 0.7$ & $-0.2 \pm 1.0$ & $17.8 \pm 1.5$ & $-1.4 \pm 0.7$ & $0.0 \pm 0.8$ \\
\hline
\end{tabular}

Age, attained height, and Diff SDS in GH-treated children during puberty, of either given dose $33 \mu \mathrm{g} / \mathrm{kg} / \mathrm{d}$ (single dose) or $66 \mu \mathrm{g} / \mathrm{kg} / \mathrm{d}$ (double dose), subdivided by gender.

Results are expressed as means $\pm \mathrm{SD}$.

Table 5. Correlations

\begin{tabular}{lccc}
\hline \multicolumn{1}{c}{ Variables: } & $\begin{array}{c}\text { Prepubertal } \\
\text { gain }\end{array}$ & $\begin{array}{c}\text { Pubertal } \\
\text { gain }\end{array}$ & $\begin{array}{c}\text { Overall } \\
\text { gain }\end{array}$ \\
\hline Auxology & & & \\
Age (y) & $-0.60^{\S}$ & $\mathrm{NS}$ & $-0.49^{\S}$ \\
Height SDS & $-0.35^{\dagger}$ & $\mathrm{NS}$ & $-0.41^{\ddagger}$ \\
Weight SDS & $-0.35^{\dagger}$ & $\mathrm{NS}$ & $-0.37^{\ddagger}$ \\
MPH SDS & $\mathrm{NS}$ & $\mathrm{NS}$ & $0.29^{*}$ \\
Diff SDS & $-0.29^{*}$ & $-0.40^{\ddagger}$ & $-0.49^{\S}$ \\
GH/IGF-I axis & $\mathrm{NS}$ & $-0.25^{*}$ & $\mathrm{NS}$ \\
GH max & $-0.41^{*}$ & $\mathrm{NS}$ & $\mathrm{NS}$ \\
IGF-I SDS & & & \\
Years with GH & $0.89^{\S}$ & $-0.31^{\dagger}$ & $0.55^{\S}$ \\
Prepubertal duration & - & - & $0.61^{\S}$ \\
Overall duration & &
\end{tabular}

Univariate correlations, expressed as $r$ values, between longitudinal gain in height and characteristics at start of GH treatment, as well as the duration of treatment.

$* p<0.05,{ }^{\dagger} p<0.01,{ }^{\ddagger} p<0.001,{ }^{\S} p<0.0001 . p$ Values and correlation coefficients with Spearman nonparametric correlation.

used, and many of the patients were either in puberty at start of treatment $(14 \%)$ or came into puberty during the first year of GH treatment (43\%). This is in accordance with our finding of a lack of further gain in height SDS during puberty, and agrees with the observation that skeletal maturation during puberty is relatively rapid (17). The rapid bone maturation that often occurs between 8 and 11 y of age among children born SGA may be the result of intrauterine programming of early puberty, rather than an effect of GH treatment.

Although the prepubertal height gain we observed is in line with findings from other studies (13-16,30), we found different correlations to height gain. Most studies report correlations with age at start of GH treatment $(13,16,30)$, one with height SDS at start (30) and others with the prepubertal GH dose $(13,15,16,30)$. We observed no correlation between response to $\mathrm{GH}$ and pretreatment height velocity. Moreover, we found that age at start and the duration of GH treatment were the strongest variables correlating with height gain. These results agree also with the study of Sas et al. (13), as well as the results from meta-analysis of four European trials (15), although neither is yet to adult height.

During prepubertal years it seems to be a dose-dependent correlation with height gain $(13,16,30)$. Interestingly, during the pubertal period we did not find a dose effect in growth response. This is in line with a randomized trial in GHD children (32), and the results of the limited impact of GH dose in prediction models of pubertal growth (33).

Among short children born AGA with GHD, the magnitude of the catch-up growth during GH treatment correlates with the Diff SDS at start $(34,35)$. We also observe a correlation with Diff SDS, although most of the children born SGA were not GHD. Some studies have found such correlation $(14,16)$, whereas others did not find this $(13,30)$. Coutant et al. (17) reported that both target height and age at start of treatment are predictors of FH. They also observed an inverse correlation with body mass index. This was also found in our study, where children with lower weight and/or body mass index grew better on GH treatment.

Our finding of a broad range in height gain in response to the given fixed dose of GH may highlight the need for individualized dosing $(34,35)$. Some of the short children born SGA may need a higher dose of $\mathrm{GH}$ to improve $\mathrm{FH}$. Validated 
Table 6. Results of the multivariate regression analysis

\begin{tabular}{|c|c|c|c|c|}
\hline Dependent variable & Independent variable & $\begin{array}{c}\text { Regression } \\
\text { coefficient }\end{array}$ & $95 \% \mathrm{CI}$ & $p$ Value \\
\hline \multirow[t]{4}{*}{ Final height (SDS) } & Father's height (SDS) & 0.20 & $0.09 / 0.31$ & 0.0005 \\
\hline & Height at start (SDS) & 0.68 & $0.93 / 0.43$ & $<0.0001$ \\
\hline & $\mathrm{GH}_{\max } \mathrm{AITT}(\mathrm{mU} / \mathrm{L})$ & -0.01 & $-0.02 /-0.00$ & 0.003 \\
\hline & Weight at start (SDS) & -0.21 & $-0.36 /-0.06$ & 0.009 \\
\hline \multirow[t]{2}{*}{ Diff SDS as adult (SDS) } & Diff SDS at start (SDS) & 0.74 & $0.60 / 0.88$ & $<0.0001$ \\
\hline & $\mathrm{GH}_{\max }$ AITT (mU/L) & -0.01 & $-0.02 /-0.00$ & 0.004 \\
\hline \multirow[t]{4}{*}{ Delta height (SDS) } & Diff SDS at start (SDS) & -0.26 & $-0.40 /-0.12$ & 0.0005 \\
\hline & Age at start (y) & -0.10 & $-0.16 /-0.04$ & 0.0005 \\
\hline & Weight at start (SDS) & -0.25 & $-0.40 /-0.11$ & 0.0008 \\
\hline & $\mathrm{GH}_{\max }$ AITT (mU/L) & -0.01 & $-0.02 /-0.00$ & 0.004 \\
\hline
\end{tabular}

Delta height, the difference between adult and pretreatment projected height in SDS. $\mathrm{GH}_{\max }$ AITT, GH maximum peak from the AITT. 95\% CI, 95\% confidence interval for the regression coefficient.

prediction models giving an index of responsiveness for each short child born SGA are useful for individualizing the dose of GH $(36,37)$.

In summary, GH treatment improves $\mathrm{FH}$ in short children born SGA. The gain achieved before puberty normalizes height during childhood in most children and is maintained through puberty to $\mathrm{FH}$, corresponding to the height of their parents. Normalization of height before puberty is essential. Duration of GH treatment for $>1 \mathrm{y}$ before puberty will improve the $\mathrm{FH}$ outcome. Younger, shorter, and lighter children at the start of GH treatment have better growth responses, are taller at onset of puberty, and achieve better FH.

Acknowledgments. The authors thank Sten Rosberg and Birgitta Svensson for technical support and Gunnar Ekeroth for statistical support, the personnel of Ward 335, and the Growth Laboratory, Queen Silvia Children's Hospital (Göteborg). We also thank the children and parents who participated. We thank the endocrine units of the university hospitals in Sweden, participating teams in the National Registry for GH Treatment, both doctors and nurses, and especially the participants in the Swedish Study Group for GH Treatment: Kerstin Albertsson Wikland, Stefan Aronson, Jan Gustafsson, Lars Hagenäs, Anders Häger, Sten Ivarsson, Berit Kriström, Karl-Olof Nilsson, Martin Ritzén, Torsten Tuvemo, Ulf Westgren, and Otto Westphal.

\section{REFERENCES}

1. Karlberg J, Albertsson-Wikland K 1995 Growth in full-term small-for-gestational-age infants: from birth to final height. Pediatr Res 38:733-739

2. Tuvemo T, Cnattingius S, Jonsson B 1999 Prediction of male adult stature using anthropometric data at birth: a nationwide population-based study. Pediatr Res. 46:491-495

3. Hokken-Koelega AC, De Ridder MA, Lemmen RJ, Den Hartog H, De Muinck Keizer-Schrama SM, Drop SL 1995 Children born small for gestational age: do they catch up? Pediatr Res 38:267-271

4. Albertsson-Wikland K, Boguszewski M, Karlberg J 1998 Children born small-forgestational age: postnatal growth and hormonal status. Hormon Res 49(suppl 2):7-13

5. Chaussain JL, Colle M, Ducret JP 1994 Adult height in children with prepubertal short stature secondary to intrauterine growth retardation. Acta Pediatr Suppl 399:72-73

6. Luo ZC, Albertsson-Wikland K, Karlberg J 1998 Length and body mass index at birth and target height influences on patterns of postnatal growth in children born small for gestational age. Pediatrics 102:E72
7. Leger J, Levy-Marchal C, Bloch J, Pinet A, Chevenne D, Porquet D, Collin D, Czernichow P 1997 Reduced final height and indications for insulin resistance in 20 year olds born small for gestational age: regional cohort study. BMJ 315:341-347

8. de Waal WJ, Hokken-Koelega AC, Stijnen T, de Muinck Keizer-Schrama SM, Drop SL 1994 Endogenous and stimulated GH secretion, urinary GH excretion, and plasma IGF-I and IGF-II levels in prepubertal children with short stature after intrauterine growth retardation. The Dutch Working Group on Growth Hormone. Clin Endocrinol (Oxf) 41:621-630

9. Albertsson-Wikland K and the Swedish Paediatric Study Group for Growth Hormone Treatment 1989 Growth hormone secretion and growth hormone treatment in children with intrauterine growth retardation. Acta Paediatr Scand Suppl 349:35-41

10. Stanhope R, Ackland F, Hamill G, Clayton J, Jones J, Preece MA 1989 Physiological growth hormone secretion and response to growth hormone treatment in children with short stature and intrauterine growth retardation. Acta Paediatr Scand Suppl 349:47-52

11. Boguszewski M, Rosberg S, Albertsson-Wikland K 1995 Spontaneous 24-hour growth hormone profiles in prepubertal small for gestational age children. J Clin Endocrinol Metab 80:2599-2606

12. Boguszewski M, Jansson C, Rosberg S, Albertsson-Wikland K 1996 Changes in serum insulin-like growth factor I (IGF-I) and IGF-binding protein-3 levels during growth hormone treatment in prepubertal short children born small for gestational age. J Clin Endocrinol Metab 81:3902-3908

13. Sas T, de Waal W, Mulder P, Houdijk M, Jansen M, Reeser M, Hokken-Koelega A 1999 Growth hormone treatment in children with short stature born small for gestational age: 5-year results of a randomised, double-blind, dose-response trial. J Clin Endocrinol Metab 84:3064-3070

14. Boguszewski M, Albertsson-Wikland K, Aronsson S, Gustafsson J, Hagenäs L, Westgren U, Westphal O, Lipsanen-Nyman M, Sipilä I, Gellert P, Muller J, Madsen B 1998 Growth hormone treatment of short children born small-for-gestational-age: the Nordic Multicenter Trial. Acta Paediatr 87:257-263

15. de Zegher F, Albertsson-Wikland K, Wilton P, Chatelain P, Jonsson B, Lofstrom A, Butenandt O, Chaussain JL 1996 Growth hormone treatment of short children born small for gestational age: metanalysis of four independent, randomized, controlled, multicentre studies. Acta Paediatr Suppl 417:27-31

16. de Zegher F, Albertsson-Wikland K, Wollmann HA, Chatelain P, Chaussain JL, Lofstrom A, Jonsson B, Rosenfeld RG 2000 Growth hormone treatment of short children born small for gestational age: growth responses with continuous and discontinuous regimens over 6 years. J Clin Endocrinol Metab 85:2816-2821

17. Coutant R, Carel JC, Letrait M, Bouvattier C, Chatelain P, Coste J, Chaussain JL 1998 Short stature associated with intrauterine growth retardation: final height of untreated and growth hormone-treated children. J Clin Endocrinol Metab 83:1070-1074

18. Ranke MB, Price DA, Albertsson-Wikland K, Maes M, Lindberg A 1997 Factors determining pubertal growth and final height in growth hormone treatment of idiopathic growth hormone deficiency. Analysis of 195 Patients of the Kabi Pharmacia International Growth Study. Horm Res 48:62-72

19. Niklasson A, Ericson A, Fryer J, Karlberg J, Lawrence C, Karlberg P 1991 An update of the Swedish reference standards for weight, length and head circumference at birth for given gestational age (1977-1981). Acta Paediatr Scand 80:756-762

20. Tanner JM, Whitehouse RH 1976 Clinical longitudinal standards for height, weight, height velocity, weight velocity and stages of puberty. Arch Dis Child 51:170-179

21. Zachmann M, Prader A, Kind HP, Hafliger H, Budliger H 1974 Testicular volume during adolescence. Cross-sectional and longitudinal studies. Helv Paediatr Acta 29:61-72

22. Karlberg J, Fryer JG, Engström I, Karlberg P 1987 Analysis of linear growth using a mathematical model. II From 3 to 21 years of age. Acta Paediatr Scand Suppl $337: 12-29$ 
23. Karlberg P, Taranger J, Engström I, Lichtenstein H, Svennberg-Redegren I 1976 The somatic development of children in a Swedish urban community. Acta Paediatr Scand Suppl 258:7-76

24. Penny R, Blizzard RM, Davis WT 1969 Sequential arginine and insulin tolerance tests on the same day. J Clin Endocrinol Metab 29:1499-1501

25. Albertsson-Wikland K, Jansson C, Rosberg S, Novamo A 1993 Time-resolved immunofluorometric assay of human growth hormone. Clin Chem 39:1620-1625

26. Jansson C, Boguszewski C, Rosberg S, Carlsson LMS, Albertsson-Wikland K 1997 Growth hormone (GH) assays: Influence of standard preparations, GH isoforms, assay characteristics, and GH-binding protein. Clin Chem 43:950-956

27. Blum WF, Breier BH 1994 Radioimmunoassays for IGFs and IGFBPs. Growth Regul 4:11-19

28. Lofqvist C, Andersson E, Gelander L, Rosberg S, Blum WF, Albertsson Wikland K 2001 Reference values for IGF-I throughout childhood and adolescence: a model that accounts simultaneously for the effect of gender, age, and puberty. J Clin Endocrino Metab 86:5870-5876

29. Blom G 1958 Statistical Estimates and Transformed Beta Variables. John Wiley \& Sons, New York

30. Ranke MB, Lindberg A 1996 Growth hormone treatment of short children born small for gestational age or with Silver-Russell syndrome: results from KIGS (Kab International Growth Study), including the first report on final height. Acta Paediat Suppl 417:18-26

31. Zucchini S, Cacciari E, Balsamo A, Cicognani A, Tassinari D, Barbieri E, Gualand S 2001 Final height of short subjects of low birth weight with and without growth hormone treatment. Arch Dis Child 84:340-343
32. Albertsson Wikland K, Alm F, Aronsson S, Gustafsson J, Hagenas L, Hager A, Ivarsson S, Kristrom B, Marcus C, Moell C, Nilsson KO, Ritzen M, Tuvemo T, Westgren U, Westphal O, Aman J 1999 Effect of growth hormone (GH) during puberty in GH-deficient children: preliminary results from an ongoing randomized trial with different dose regimens. Acta Paediatr Suppl 88:80-84

33. Ranke MB, Lindberg A, Martin DD, Bakker B, Wilton P, Albertsson-Wikland K, Cowell CT, Price DA, Reiter EO 2003 The mathematical model for total pubertal growth in idiopathic growth hormone $(\mathrm{GH})$ deficiency suggests a moderate role of $\mathrm{GH}$ dose. J Clin Endocrinol Metab 88:4748-4753

34. Ranke MB, Lindberg A, Chatelain P, Wilton P, Cutfield W, Albertsson-Wikland K, Price DA 1999 Derivation and validation of a mathematical model for predicting the response to exogenous recombinant human growth hormone $(\mathrm{GH})$ in prepubertal children with idiopathic GH deficiency. KIGS International Board. KABI Pharmacia International Growth Study. J Clin Endocrinol Metab 84:1174-1183

35. Wikland KA, Kriström B, Rosberg S, Svensson B, Nierop AF 2000 Validated multivariate models predicting the growth response to $\mathrm{GH}$ treatment in individual short children with a broad range in GH secretion capacities. Pediatr Res 48:475-484

36. Ranke MB, Lindberg A, Cowell CT, Wikland KA, Reiter E, Cowel, Price DA 2003 Prediction of response to growth hormone in short children born small for gestational age: analysis of data from KIGS (Pharmacia International Growth Database). J Clin Endocrinol Metab 88:125-131

37. Dahlgren J, Albertsson Wikland K 2002 Short children born SGA-How to best predict growth response to GH treatment. Horm Res 58(suppl 2):164 